\title{
RRP15 Gene
}

National Cancer Institute

\section{Source}

National Cancer Institute. RRP15 Gene. NCI Thesaurus. Code C114394.

This gene is involved in ribosomal RNA processing. 